\title{
Invisible, Unfettered and Predictable-The Patterning of Corporate Political Activity in the UK
}

\author{
Mama Z. Kone' ${ }^{1}$ Tom Farnhill2* \\ ${ }^{1}$ Aston Business School, Birmingham, UK \\ ${ }^{2}$ University of Birmingham, Birmingham, UK \\ Email: kzeinab77@gmail.com, ^thomas.farnhill@gmail.com
}

How to cite this paper: Kone, M.Z. and Farnhill, T. (2019) Invisible, Unfettered and Predictable-The Patterning of Corporate Political Activity in the UK. Open Journal of Business and Management, 7, 1779-1802. https://doi.org/10.4236/ojbm.2019.74123

Received: August 23, 2019

Accepted: September 24, 2019

Published: September 27, 2019

Copyright (๑) 2019 by author(s) and Scientific Research Publishing Inc. This work is licensed under the Creative Commons Attribution International License (CC BY 4.0).

http://creativecommons.org/licenses/by/4.0/

\section{(c) (i) Open Access}

\begin{abstract}
Corporate interests' access to the UK Cabinet Office shows that corporate political activity in the UK is common, involving lobbying by large numbers of businesses from a wide range of industrial sectors-albeit with considerable sectoral variation. Firm size appears to be the most deterministic variable-larger firms enjoy significantly more access to government than small and medium-sized firms. However, most lobbying is undertaken by domestic firms-multinational firms, despite their size, may concentrate their lobbying on supranational institutions. Associations representing smaller businesses are also underrepresented. The patterning and behaviour of corporate political activity in the UK-largely unregulated-mirrors that of jurisdictions where it is more regulated and monitored; inviting either a reappraisal of the impact of regulation on lobbying or a consideration of why UK lobbying, unfettered and relatively invisible, behaves in an identical manner.
\end{abstract}

\section{Keywords}

Corporate Political Activity, Governance, Lobbying

\section{Introduction}

Although understood using frameworks originally designed to understand relations between the state and interest groups generally [1] [2] [3], recent research has identified a range of corporate-specific factors influencing businesses' motivations for engaging in corporate political activity (CPA) [4] [5] [6]. According to Dowding [7] CPA has increased considerably over the last 20 years and yet the practice remains controversial [6] [8]. In the UK the 2014 Transparency of Lobbying, Non-party Campaigning and Trade Union Administration Act was 
passed as part of wider efforts to clean-up British politics in the wake of the 2009 expenses scandal, requiring professional lobbying organisations engaged in accessing senior politicians and civil servants to register with the newly created Office of the Registrar of Consultant Lobbyists and to disclose the names of their clients. The Act does not, however, cover organisations that lobby directly. So in addition to being controversial much lobbying remains invisible-and relatively under-researched [8].

This article uses 2014-15 data released as part of the UK Government's Open Data Initiative (ODI) to explore how CPA is patterned and the exogenous and endogenous characteristics shaping businesses' access to political decision-makers. The data provides a snapshot of interactions between firms and the UK Cabinet Office. The Cabinet Office is effectively responsible for overseeing and synchronising the work of other government departments and ensuring that the government's agenda is followed. It extends the reach of the Prime Minister's Office and therefore also influences policy formation and implementation. The Cabinet Office's centrality to UK policy making-and non-sectoral brief-made it an ideal vehicle with which to explore differential access. We use broad brushstrokes to understand the general patterning of UK CPA (rather than produce detailed explanations of why certain firms and sectors may fare better than others). Our findings confirm the essentially pluralist texture of the UK political economy through the sheer numbers of individual businesses participating in lobbying, drawn from most of the UK's industrial sectors.

Nevertheless, there is sectoral variation, with some achieving greater access than others. Some of this probably reflects the relative importance of specific policy sectors (to government) which may also be subject to ebbs and flows as political and economic priorities shift according to inter alia internal and external political and economic shocks, the opening and closing of policy windows and the vagaries of public opinion [9] [10]. Sectoral variation may also reflect the abilities of businesses within specific sectors to successfully operationalise an effective CPA strategy.

Concretely, perhaps the most obvious finding concerns the relationship between firm size and access. Micro, small and medium-sized businesses achieved very little access. That large firms dominate is unsurprising-they possess the access goods desired by governments and the resources to develop effective lobbying strategies. But given that large firms constitute less than $1 \%$ of all UK businesses and employ less than $50 \%$ of the UK workforce [11] it is possible to argue that a rather elitist brand of pluralism is in operation dominated by an unrepresentative sample of the UK's corporate universe.

The research also showed that transnational corporations are probably concentrating their corporate political activity elsewhere and most meetings with the Cabinet Office involved domestic businesses. The wider point here is that businesses are rational, self-interested actors which choose their targets carefully [6]. National government, concerned with national political and economic agendas, will also be especially porous to domestic interests which are better able 
to assist them with national policymaking.

The general exclusion of small and medium sized enterprises (SME) extends to their peak representative body too. It is the Confederation of British Industry (CBI) - which represents the UK's largest firms - rather than the Federation of Small Businesses (FSB) which has enjoyed most access. But it is equally possible that the SME sector's magnitude and diversity is such that its representative bodies are themselves unrepresentative and/or disorganised and therefore less able to achieve insider status.

Finally, it would appear that a mixture of transactional and relational lobbying is being practised. The large numbers of businesses meeting the Cabinet Office on a more or less one-off basis suggest they are simply reacting to proposed policy reforms. At the same time, some businesses are enjoying repeated encounters with the Cabinet Office, suggesting a relational approach in operation.

More widely, the findings show that the patterning of UK lobbying is similar to lobbying in other comparable jurisdictions, including those where it is regulated more and which we therefore understand better. On the one hand this is not surprising if the comparators are also modern liberal economies. But it begs the question: what, exactly, is the point of monitoring and regulation if its presence or absence has no significant effect on corporate behaviour?

The article commences by drawing on the literature (necessarily from jurisdictions where CPA is more heavily regulated) to define lobbying; identify what is known about why and how it occurs and the motivations of its main actors. This is used to generate a limited number of informed propositions. After a brief description of the methodology the results of the analysis are described and evaluated using these propositions.

\section{Defining Corporate Lobbying}

Most simply, any direct contact between firms and government representatives - via either formal or informal routes — constitutes lobbying [12] [13] [14] argue that direct contact between firms and government representatives typically occurs across the policy cycle, not just when government is proposing a particular policy-this reflects the growing role of business in the implementation and evaluation of policy and their desire to exercise influence over the general political and economic conditions within which they operate.

CPA may constitute part of a firm's public relations strategy focusing on achieving organisational aims through the creation and maintenance of positive relations with external stakeholders which includes both state and non-state actors. Firms may, for example, seek to engage with the media or directly with the public [15] in order to influence opinion on topics that affect the firm's fortunes directly or indirectly. Historically, much research investigating lobbying has homogenised its non-state dramatis personae [16] [17], but more recent research has identified a range of corporate-specific factors influencing firms' motivations for engaging in CPA and their action repertoire [6] [18] [19]. 


\section{The Rise of Lobbying}

Lobbying has increased significantly over the past 20 years [20]. This is in part due to a proliferation of (interacting and resource dependent) non-state actors, many of whom are interested in influencing the policymaking agenda, acting either unilaterally or via coalitions [21]. Much literature differentiates lobbyists on the basis of their strategies and success [22] [23] with theorists typically classifying them as "insiders" or "outsiders" [24]. "Insiders" include those non-state actors which enjoy close working relationships with political decision-makers-routinely consulted "go to" actors [5] —whilst "outsiders" include groups yet to achieve "insider" status (such as those lacking resource capability) or those eschewing such status, preferring instead to operate outside the formal machinery of government in order to avoid incorporation and/or preserve the freedom to pursue a wider action repertoire [25] [26]. Understanding the increase in CPA requires investigating the political environment which facilitates or constrains corporate lobbying but also the corporate-specific objectives of those participating.

According to Grant [27] and Miller [28] the increase in CPA is partly attributable to the decline of UK corporatism since the 1980s. During the 1960s and 1970s businesses (and trade unions) were automatically treated as "insiders" by government and so did not need to lobby concertedly [29]. During the 1980s, however, corporatism was replaced by neoliberal statecraft [30]. Under the administrations of Margaret Thatcher and John Major this was, by instinct, pro-business [31] and characterised by a shift from "government" to "governance". The concept of "governance" posits that "government" is no longer the dominant policymaker. Instead, policymaking is multi-level and network-based, comprising large numbers of non-state actors [2]. On the one hand this has been understood as the simple demise of the traditional "command and control" mode of government [32]. Alternatively, Rhodes [33] argues that "governance" represented a renewal of state power designed to (re)legitimise an overloaded state and improve policy implementation. Under the governance model the state concentrates on policymaking-leaving policy delivery to second- and third-sector actors [2].

But, of course, the separation between policy formation and policy delivery is an artificial one-legislators responsible for drafting policy must factor-in knowledge of how and whether it can be implemented; and those responsible for implementation must do so in a manner that achieves the policymakers' objectives [34] [35]. The governance model therefore reconfigured (rather than supplanted) corporate interests' involvement in policymaking [36]. "Governance" also incentivised CPA [3] - reducing the role of the state and increasing the responsibilities of non-state actors to deliver policies was achieved via processes of marketization, privatisation and deregulation [31] [37], so alongside firms' traditional lobbying agendas (e.g. trade policy; investment policy; employment law; corporate taxation) were new and considerable financial opportunities to be realised via a hyper-competitive "market" for influence [5] [18] [37] [38] [39]. 


\section{Lobbying: "Good" or "Bad"?}

To pluralists, the state acts as a referee and is a relatively neutral actor in the political and economic decision-making landscape [40]. Power is evenly distributed across society and the full range of non-state actors are free to participate in the policy-making process using a range of tactics of which lobbying is just one [41]. Pluralists argue that the state is (or should be) porous, so that access to government-and influence-is not concentrated in the hands of a limited number of elite actors [42]. But, according to Kooiman [43] and Baldwin et al. [44] public policy problems and policymaking processes are complex-therefore it is not unreasonable to expect participation to sometimes be dominated by affected parties who possess the expertise to contribute effectively. Neither are pluralists overly concerned with reasonable amounts of secrecy-given sensitivities around policymaking (particularly policies which may generate winners and losers or which are at an exploratory stage) it may be sensible for such processes to occur in camera.

Porous systems of policymaking wherein a multiplicity of non-state actors are free to access governments and contribute to policymaking therefore provide policymakers with information and analysis resulting in smarter policies [27] [45]. Pluralists consider this approach more desirable than having lots of non-state actors engaging in direct action in an attempt to mobilise popular support and bypass established policymaking processes, where policymaking reflects the interests of those who shout the loudest. According to pluralists, then, lobbying is an essential component of democracy and contemporary politics-necessarily complex behind-the-scenes deliberations in corridors of power inoculated from the showbusiness of party politicking [46] [47]. The impact of having so many actors involved in the policymaking process is, of course, contested. Lindblom [48] argues that it privileges cautious, incremental policies which enjoy wide support. Alternatively, the policies most likely to emerge from such processes may not be those that are needed but, rather, those that simply attract the least opposition.

Neopluralists insist that power is unequally distributed across interest groups and it is inevitable that certain interests will exercise greater influence than others [41]. Neopluralists also argue that the state is a particularly powerful interest in its own right [49]. Although neopluralists are not instinctively opposed to lobbying the implications are clear-unchecked, rather than generating smarter policies and promoting open, deliberative and genuine evidence based policymaking processes, lobbying will be used by powerful elites to pursue their own self-interest [1]. At the very least, patronage and secrecy rarely look good.

Such concerns-as well as concerns about outright corruption-typically inform demands that lobbying must be regulated and rendered transparent and accountable. Regulation, where it exists, may require lobbyists to:

- Sign-up to a code of conduct;

- register with an appropriate public body; 
- disclose the identities of their clients;

- disclose the identities of the public actors they are targeting;

- disclose the subject matter to be lobbied;

- disclose how much money they are spending;

- limit how much money they spend.

The classification scheme developed by Chari et al. [50] groups different countries' approach to the regulation of lobbying into three main categories-"high"; "medium" and "low"-according to the presence or absence of these requirements and how effectively they are implemented. They argue that cogent lobbying regulations exist in just nine political systems in the democratic world: Australia; Canada; the EU (Parliament; Council and Commission); Germany; Hungary; Lithuania; Poland; Taiwan and the US.

This article is focused on understanding the patterning of lobbying in the UK, where it remains largely invisible, and remains silent on the matter of whether or not lobbying is "good" or "bad" (and therefore in need of regulating). Indeed, we are not sure what criteria could be used to construct lobbying as such. Meetings held in camera may sometimes be appropriate because of the topic being discussed and the precise stage at which deliberations are at [4] [38]. Similarly, it is not automatically unreasonable for government officials to limit their interactions to those non-state actors considered most expert [51]. The desirability of lobbying, then, cannot unproblematically be reduced to either secrecy or a "numbers game". Value judgments regarding the desirability of lobbying must also factor-in outcomes and evaluate whether or not policies have benefitted from the participation of non-state actors and serve the wider public interest [52] [53]. These are matters which cannot be extrapolated from the ODI data and are also methodologically problematic, requiring high-level access (to firms and political decision-makers), an operationalisable definition of 'the public interest' and a way of measuring the firm's input facilitating an assessment of what the policy might have looked like had lobbying not occurred. These are beyond the remit of this article.

\section{Why Lobby?}

\subsection{Lobbying from the Government's Perspective}

Most obviously, at the policy formation stage lobbying can constitute part of an informal or formal consultative strategy [8]. Here, governments are seeking several things. They may welcome the input of non-state actors in order to acquire intelligence to create smarter policies [11]. Governments may also use the participation of non-state actors in decision-making as a way of conferring legitimacy onto their policy proposals [54], assess the potential popularity of a policy and gauge the likelihood—and strength—of any opposition [27].

\subsection{Lobbying from the Firm's Perspective}

Despite the shift from "government" to "governance" much UK policymaking is 
centralised [7] and firms continue to see the British state as an important "target" of their CPA [55]. Firms are mainly concerned with their own survival [6] and lobby in order to achieve policy domain advantage, defence or maintenance and to reduce uncertainty [56] [57]. Although historically most lobbying was essentially defensive-seeking to prevent governments from adopting policies perceived as harmful to the firm and a means of gaining competitive advantages via favorable regulation-much contemporary lobbying is also aggressive and explicitly designed to raise rivals' costs [10] [58].

\section{The Patterning of Lobbying}

The literature identifies several factors which may shape who does-and does not-participate in lobbying. This section summarises several of the most influential, with particular attention paid to those which facilitate analysis of the ODI data.

\subsection{Porosity of the State}

Lobbying takes place within a political opportunity system comprising a range of "friendly" and "unfriendly" state and non-state actors and it is, of course, inevitable that actors will encounter and interact with each other. In the UK, the shift from "government" to "governance" created new incentives for firms to lobby, underpinned by a belief that the private sector was more efficient [1]. It is a porous, pro-business polity, providing fertile lobbying ground. Nevertheless, the UK's policymaking architecture is complex-a heady mix of centralised and decentralised processes presenting prospective lobbyists with multiple jumping-in points; some of which may be more accessible and useful than others [54] [59]. This is important because in the EU Greenwood [26] and Eising [19] found that only businesses with the knowledge and resources to navigate complex political policymaking institutions were able to lobby effectively and this expertise is not easily acquired.

\subsection{Power}

Indeed, Hillman and Hit [23] argue that smaller firms are less likely to engage in lobbying by themselves-they neither possess the resources nor sufficient access goods. According to Boleat [60] business associations tend to represent the interest of smaller businesses. Correlatively, larger firms are more likely to lobby, and to do so independently [61]. This can be understood using coalition and network theory. According to Hojnacki [62] and Obach [63], non-state actors may be "weak" or "strong". Coalition theory suggests that weak groups need strong groups to press home their claims with governments but strong groups do not need weak groups and can act unilaterally. Further, coalition-building is in itself a resource-intensive activity which groups do not embark upon lightly. Coalition theory therefore suggests that non-state actors' propensity and ability to lobby may be circumscribed by inter alia their power relative to the power and 
influence of other relevant actors [21]. Network theory examines the concept of "interdependence" in more detail. According to Rhodes [2] non-state actors may coalesce into networks in order to advance their interests, including objectives which individual members could not easily achieve. Networks vary in terms of membership, cohesiveness, size, porosity, influence and stability and power may not be evenly distributed within them [47]. But Rhodes insists that networks are now key actors within the UK's policymaking landscape. Coalition theory and the network model both, therefore, demonstrate that lobbying does not occur in a vacuum - it is a contingent activity which occurs in a crowded political system which circumscribes precise behaviours, reflecting the power asymmetries and interdependencies of its actors.

\subsection{Sectoral Specificities}

Certain policy domains are characterised by more intense and frequent lobbying than others. Stable policy domains-those where there is broad agreement between parties regarding policy objectives and where the political costs of policy failure are low-may not require their non-state actors to lobby because their interests are generally being met [5] [56]. But unstable, tricky policy domains-those characterised by complexity, political sensitivity and contested objectives [64] — can require ongoing maintenance and may instead feature considerable political activity. Slightly differently, Hawkins and Holden [8] argue that corporate interests in highly specialised policy domains-about which governments know little-rarely lobby and are likely to be left alone, experiencing little difficulty in uploading their concerns onto government when necessary.

\subsection{International-Ness}

Transnational corporations wield significant power, possess considerable access goods and can be understood differently to other (weaker) corporate interest groups. Lawton, et al. [14] argue that transnational firms engage in significant levels of lobbying but much of it occurs supranationally or with selected national governments whose economic and industrial priorities align with their own. Because of such "venue shopping", although national governments can benefit from entering into relationships with transnational corporations [65], transnational corporations can consider relations with national governments relatively unimportant.

\subsection{Policy Process View}

The patterning of lobbying can also be understood in more processual terms. Downs's [66] "attention cycle" is arguably the most well-known model explaining how policy problems can move in and out of view (particularly in the media) prompting ebbs and flows in policymaking activity. But theorists such as Kingdon [67] also argue that policymaking activity occurs at certain times and under certain conditions_-an issue must be recognised as a problem (requiring state 
intervention); there must be a solution at hand; and an opportunity "window" must open during which time policymaking activity can occur. Some policy windows are predictable (the run-up to a general election for example) whilst others are not (e.g. economic crises); and windows may not remain open for long [68]. The point is that lobbying opportunities-mirroring the problems they attend to- "come and go"; and firms must be ready to respond to them with solutions.

\section{Transactional and Relational Lobbying}

According to Getz [12] lobbying can be seen as a transaction where firms must give something to the government in exchange and it is often undertaken on an issue-by-issue basis [23]. In contrast, relational lobbying is less obviously instrumental. Here, firms are focused on developing long-term working relationships with government [69]. Even so, according to Anastasiadis [70] both approaches pivot around a similar set of concerns: "information"; "communication"; "reputation" and "outcomes".

The transactional approach may involve providing politicians with information and analysis or even financial support [6]. But the approach is also associated with conflict because it is typically aimed at preventing an unwanted government policy [5]. Firms engaged in transactional lobbying are not averse to constituency building-mobilising constituents (anyone adversely affected by a policy or intended policy, including the public qua consumers and taxpayers; suppliers and other firms) and coordinating active opposition [21] [70].

The relational approach seeks to minimise conflict by promoting shared understandings through the creation and maintenance of durable, interdependent, mutual gains relationships. It reflects the view that policymaking is not just about the exercise of power but also about ideas and collective "puzzle solving"-a process of social learning [16] [20].

Various factors affect firms' decisions to adopt a particular approach including the firm's perception of how government policy is likely to affect it and the political environment within which it operates (crudely, pluralist environments facilitate transactional lobbying whilst corporatist environments facilitate relational lobbying) [23]. Domain specificities are also important in influencing approaches: for example, in complex and dynamic domains lobbying is likely to be more common; and firms in these sectors are more likely to practice relational lobbying rather than address matters on an inefficient ad hoc transactional basis.

\section{The Propositions}

On the basis of the above it is possible to identify a number of informed propositions that can be tested against the ODI data:

1) the UK economy is essentially pluralist and the state is relatively porous to non-state actors and generally pro-business. Further, the Cabinet Office is an especially powerful government body and a key target for corporate interests. 
For both these reasons we should expect lobbying to be a reasonably common activity

2) lobbyists from many sectors will feature but there will be sectoral variation. This may reflect inter alia domain specificities, legacy and wider social, political and economic developments wherein policymaking activity "moves" from sector to sector in accordance with shifting priorities, attention cycles, crises and the opening and closing of policy windows

3) larger, influential, resource-rich firms will feature far more prominently than smaller firms

4) genuinely transnational corporations may be relatively underrepresented; but this may be because they tend to lobby at an international level

5) umbrella organisations are likely to be from sectors featuring small and relatively weak corporate interests that individually lack the resources and access goods required to achieve access

6) CPA will comprise a mixture of transactional and relational lobbying

\section{Methodology}

The research uses data released as part of the ODI providing details of meetings between the Cabinet Office and large numbers of corporate and non-corporate interests during 2014-15. This resulted in a sample comprising the activities of 388 companies and 15 businesses associations. Additional datasets and sources (including the Office of National Statistics; Fame company and financial database; Companies House and firms' own websites) were accessed to obtain details of individual firms-including size and standard industrial classification (SIC).

\section{Presentation of Data}

\subsection{Overview}

Economic activities in the UK are grouped into 18 SICs. Figure 1 provides a sectoral breakdown showing the total number of firms achieving access to the Cabinet Office; the total number of actual meetings; and those sectors which are "punching" above or below their weight compared to their relative presence in the UK economy as a whole (the ratios were arrived at by dividing the number of meetings from each individual sector by the total number of businesses in each sector in the UK economy).

In 2014-2015, 388 businesses met the Cabinet Office, involving 13 SICs and 676 separate meetings (excluding 25 meetings with Business Associations and six meetings with "Other Services"). Figure 1 shows that access to the Cabinet Office is uneven, with several sectors achieving very limited access. Firms from the Information and Communication (212); Manufacturing (113); Finance and Insurance (76) and Professional, Scientific, Technology (75) sectors have been most active, accounting for over $67 \%$ of all meetings. In terms of the numbers of separate firms involved, those from the Information and Communication (74); Manufacturing (68); Finance and Insurance (49); and Professional, Scientific, 




Figure 1. Sectoral breakdown of access to the Cabinet Office 2014-2015.

Technology (45) sectors are again the most active, accounting for over $60 \%$ of all encounters. These are also amongst the highest contributors to UK GDP (Office for National Statistics [71]): Information and Communication (7\% of GDP); Manufacturing (10\%); Finance and Insurance (6.5\%); Professional, Scientific and Technology (11\%). Of all the sectors achieving access to the Cabinet Office the Transportation and Storage sector is interesting because it enjoyed very limited access despite its major contribution to the UK economy (11\%).

Figure 1 uses ratios to express which sectors are achieving high/low access relative to their presence in the UK economy overall. The ratios were calculated by dividing the number of meetings from each individual sector by the total number of businesses operating in each sector in the UK. We should expect, if equally distributed, 0.0013 meetings with the Cabinet Office for every one business in all 13 sectors represented. But three sectors achieved disproportionately greater access: Mining, Quarrying and Utilities and, to a much lesser extent, Finance and Insurance and Information and Communication sectors.

Finally, Figure 1 also shows that certain sectors' firms enjoyed repeated access. This is most obviously the case when the "gap" between No. of Individual Firms and No. of Meetings is large. This is illustrated more clearly in Figure 2, where the number of meetings per sector was divided by the number of firms involved to generate an "activity quotient" indicating the presence of repeated 


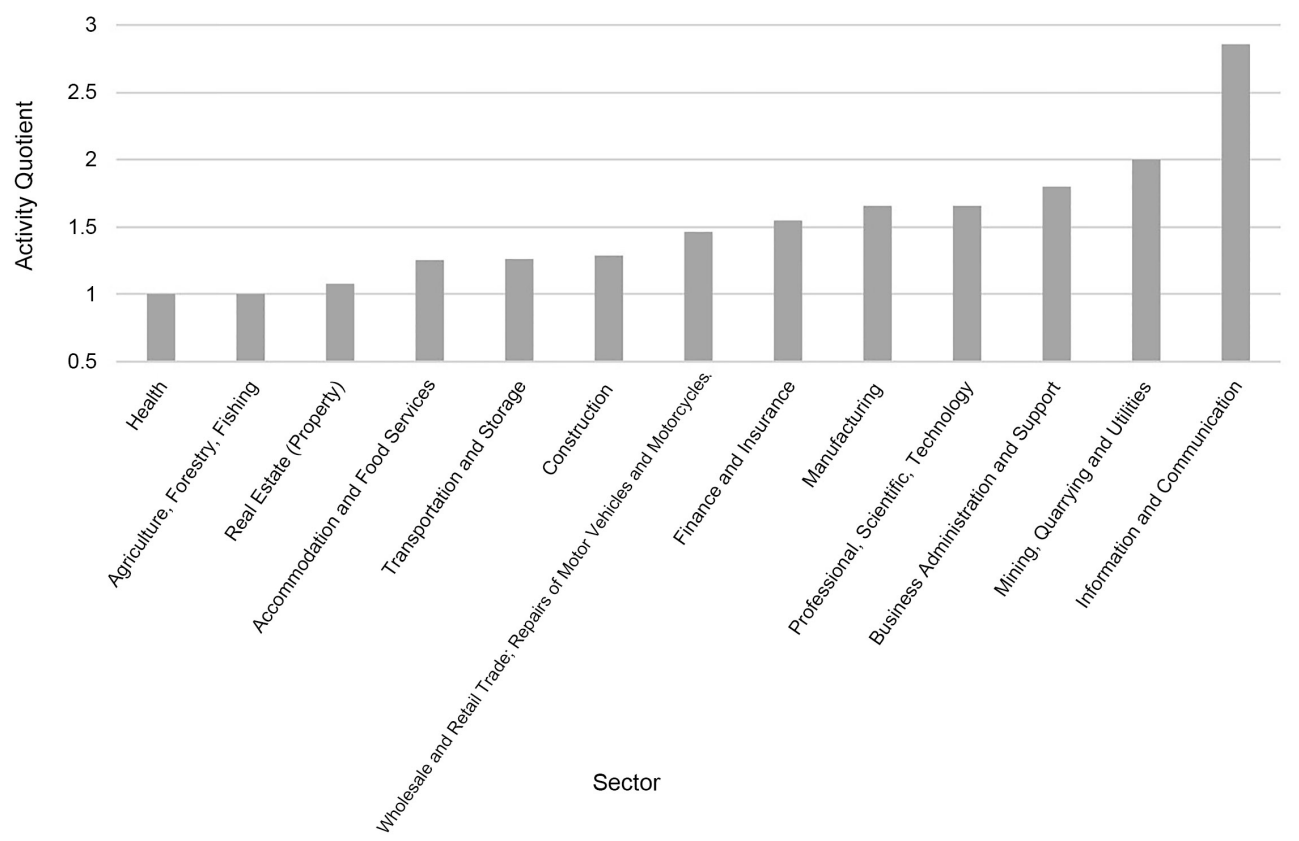

Figure 2. Sectoral breakdown of firms' repeated access to the Cabinet Office 2014-2015.

access. This is a crude measure, admittedly, which does not always indicate precisely how the meetings were distributed amongst the firms. But it presents useful headline figures showing those sectors' whose firms (at the upper end of the scale) are most likely to have met the Cabinet Office more than once and those sectors' (at the lower end) where meetings are generally limited to one-off encounters. Firms from the Information and Communication sector appear to have had most success-assuming access is evenly distributed, each of the 74 firms involved met the Cabinet Office on almost three occasions.

\subsection{Firm Size}

Figures 3-5 provide a breakdown of meetings with the Cabinet Office by firm size (number of UK employees). Firms for which accurate information was not readily available are excluded from the analysis (resulting in a sample of 143 firms involved in 140 meetings). Figure 3 shows that large companies have greater access to the Cabinet Office than micro, small or medium sized businesses. It is also evident that large firms punch significantly above their weight in the "corridors of power" compared to their numerical presence in the wider economy. Again, if equally distributed across the 13 sectors, for every one firm in the UK economy, regardless of size, we should expect 0.0013 meetings-but for large firms the actual figure is 0.015 . Large firms' access exceeds that of medium-sized firms by a factor of 18; of small firms by a factor of 524; and of micro firms by a factor of 5000. Parenthetically, large firms are responsible for just $49 \%$ of the UK's economic turnover (small firms generate 37\% and medium-sized firms $15 \%$ ) - that they account for over $74 \%$ of meetings with the Cabinet Office is further evidence of their dominance. 


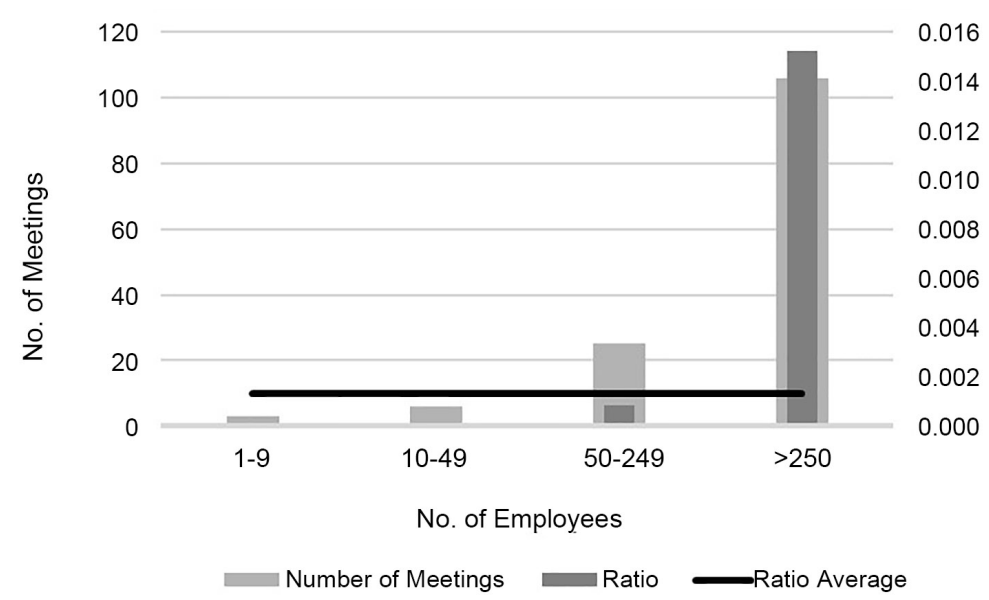

Figure 3. Firm size and access to the Cabinet Office 2014-2015.

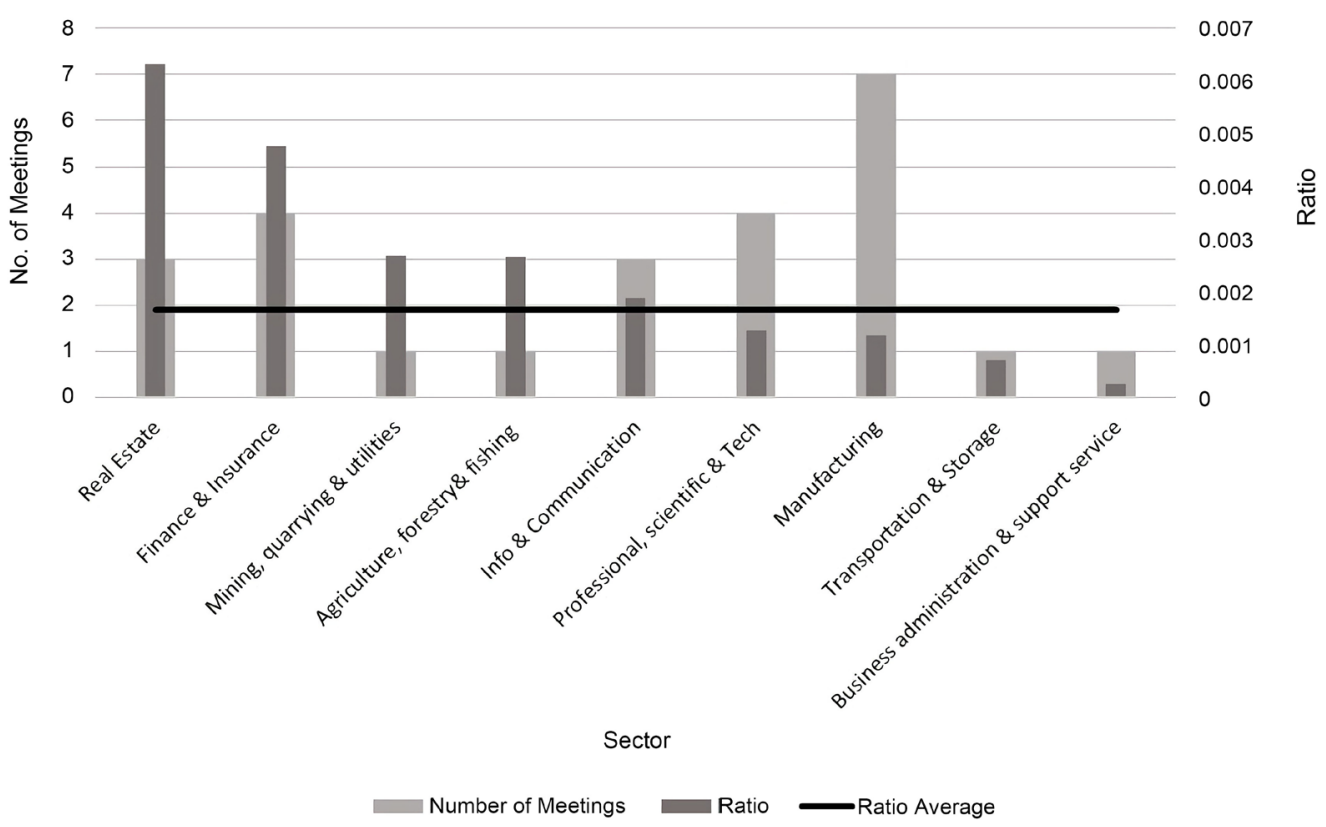

Figure 4. Sectoral breakdown of medium-sized firms' access to the Cabinet Office 2014-2015.

\subsection{Firm Size and Sector-Micro- and Small-Businesses}

Micro businesses (firms employing 1 - 9 employees) enjoyed barely any access to the Cabinet Office-two meetings were held with firms from the Finance and Insurance sector and one meeting was held with one firm from the Construction sector. The situation for Small businesses (10 - 49 employees) is similar, with just six meetings involving small firms from just 5 sectors-Information and Communication (2); Finance and Insurance (1); Transportation and Storage (1); Wholesale and Retail Trade, Repairs of Motor Vehicles and Motor Cycles (1) and Professional, Scientific and Technology (1). It may be that micro and small businesses do not feel that the Cabinet Office is an appropriate target for their concerns; but may also individually lack the access goods, expertise and resources to lobby effectively [6] [61]. 


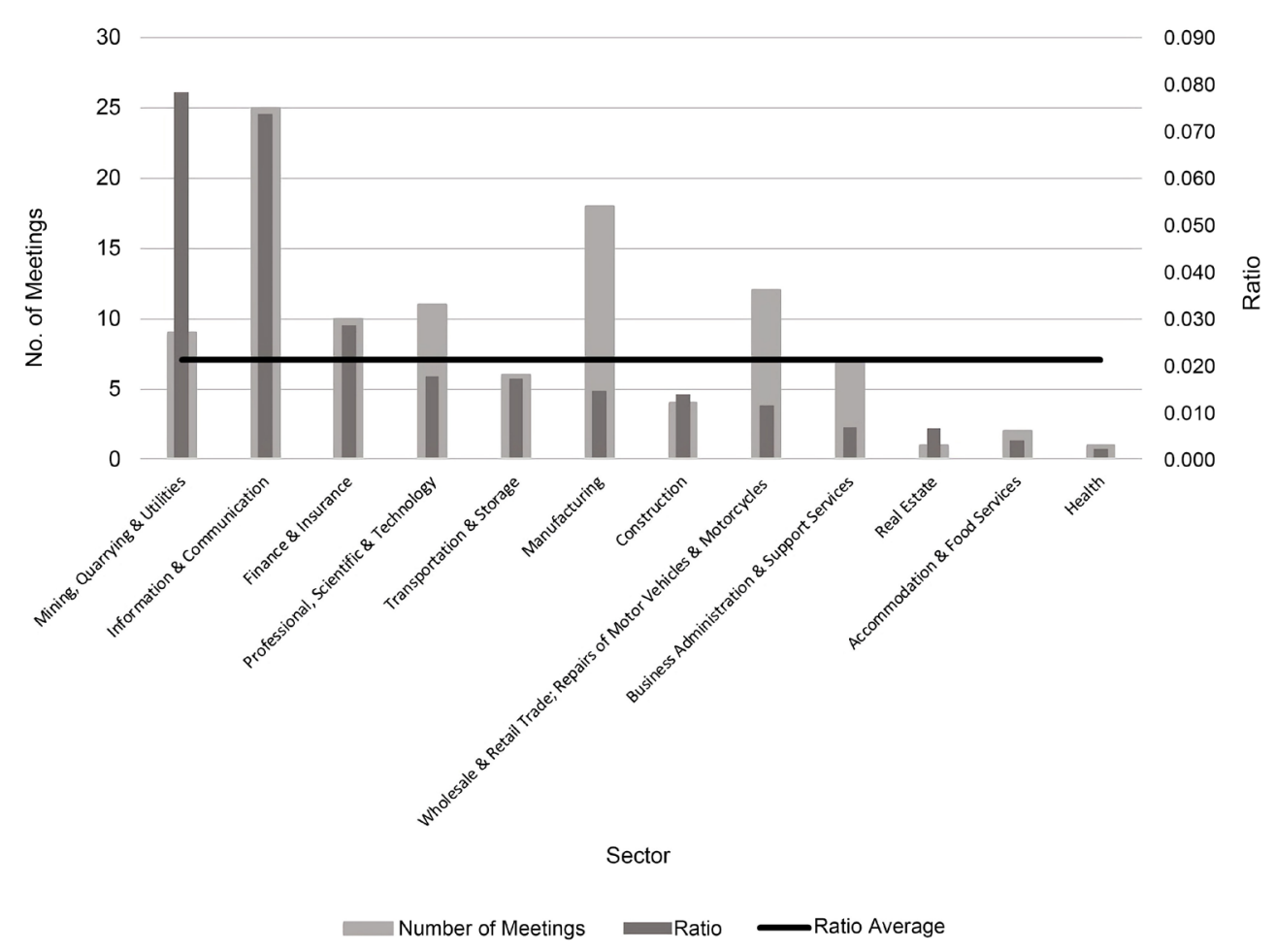

Figure 5. Sectoral breakdown of large firms' access to the Cabinet Office 2014-2015.

\subsection{Firms Size and Sector-Medium-Sized Firms}

Figure 4 shows data for medium-sized companies (50 - 249 employees). Only four sectors are now unrepresented and there is a general increase in the number of meetings held. Meetings with firms from the Manufacturing sector were most common, but several sectors were also highly successful relative to their presence in the overall economy-if equally distributed we should expect 0.0016 meetings for every one medium-sized firm across the economy in the nine sectors represented. But firms from the Real Estate; Finance and Insurance; Mining and Utilities and Agriculture, Forestry and Fishing sectors all punched above their weight.

\subsection{Firm Size and Sector-Large Firms}

Figure 5 shows data for large companies ( $>250$ employees). Here, large firms from just the Agriculture, Forestry and Fishing sector did not secure access (there are probably not many large firms in this sector) and the number of meetings held is much higher. Large firms from the Information and Communication and Manufacturing sectors achieved most access; whilst those from the Mining, Quarrying and Utilities; Information and Communication (and, to a lesser extent, Finance and Insurance) sectors were the most successful relative to their presence in the overall economy.

Size presents as an important variable in the patterning of corporate political activity-smaller firms achieved much less access to the Cabinet Office than larger firms. There is also sectoral variation, with firms from some sectors achiev- 
ing disproportionately high levels of access, although firms from relatively small sectors can still secure an audience.

\subsection{International-Ness}

According to Table 1, domestic (nationally based) firms have had more encounters with the Cabinet Office than international firms both in terms of the number of separate firms accessing the Cabinet Office and the overall number of encounters, suggesting that international companies' CPA may be directed towards international political, economic and sectoral institutions.

There is, however, discernible sectoral variation: international firms from five sectors were more active than their wholly or mainly domestic equivalents (Construction; Finance and Insurance; Manufacturing; Mining, Quarrying and Utilities; Real Estate). And in terms of the numbers of actual meetings, international firms from four sectors were more active than their domestic equivalents (Accommodation and Food Services; Business Administration and Support Services; Construction; Transportation and Storage).

\subsection{Umbrella Organisations}

Table 2 focuses on umbrella business organisations. The CBI-large firms' peak

Table 1. Domestic and transnational firms' access to the Cabinet Office 2014-2015 by sector.

\begin{tabular}{|c|c|c|c|c|}
\hline Economic Sectors & $\begin{array}{l}\text { Number of domestic } \\
\text { firms lobbying }\end{array}$ & $\begin{array}{l}\text { Number of } \\
\text { international } \\
\text { firms lobbying }\end{array}$ & $\begin{array}{c}\text { Number of } \\
\text { meetings involving } \\
\text { domestic firms }\end{array}$ & $\begin{array}{c}\text { Number of } \\
\text { meetings involving } \\
\text { international firms }\end{array}$ \\
\hline Accommodation and Food Services & 2 & 2 & 2 & 3 \\
\hline Agriculture, forestry and fishing & 1 & 0 & 1 & 0 \\
\hline Business Administration \& Support Service Activities & 18 & 8 & 21 & 26 \\
\hline Business Associations & 13 & 2 & 23 & 2 \\
\hline Construction & 7 & 10 & 9 & 13 \\
\hline Education & 1 & 1 & 1 & 1 \\
\hline Finance and Insurance & 21 & 28 & 39 & 37 \\
\hline Health & 2 & 1 & 2 & 1 \\
\hline Information and Communication & 49 & 25 & 136 & 76 \\
\hline Manufacturing & 28 & 40 & 65 & 48 \\
\hline Mining, quarrying \& utilities & 11 & 14 & 29 & 21 \\
\hline Professional, scientific \& technical activities & 29 & 16 & 38 & 37 \\
\hline Real Estate (property) & 5 & 7 & 5 & 8 \\
\hline Other services & 3 & 3 & 3 & 3 \\
\hline Transportation and Storage & 9 & 6 & 12 & 7 \\
\hline $\begin{array}{l}\text { Wholesale and retail trade; repairs of motor vehicles } \\
\text { and motorcycles }\end{array}$ & 20 & 6 & 32 & 6 \\
\hline Total & 219 & 169 & 418 & 289 \\
\hline
\end{tabular}


Table 2. Business associations access to the Cabinet Office 2014-2015.

\begin{tabular}{|c|c|c|c|c|}
\hline Organisation & $\begin{array}{l}\text { Number of } \\
\text { meetings }\end{array}$ & $\begin{array}{c}\text { International/ } \\
\text { National/Regional }\end{array}$ & Sector & Membership \\
\hline Confederation of British Industry & 10 & National & Multi-sectoral & Large Businesses \\
\hline North East Chamber of Commerce & 1 & Regional & Multi-sectoral & Micro-businesses to Large businesses \\
\hline Norfolk Chambers of Commerce & 1 & Regional & Multi-sectoral & Micro-businesses to Large businesses \\
\hline $\begin{array}{l}\text { Lowestoft and Waverney } \\
\text { Chambers of Commerce }\end{array}$ & 1 & Regional & Multi-sectoral & Micro-businesses to Large businesses \\
\hline Federation of Small Businesses & 1 & National & Multi-sectoral & SMEs \\
\hline $\begin{array}{l}\text { British Bangladesh Chamber of } \\
\text { Commerce and Industry }\end{array}$ & 1 & Bi-lateral & Multi-sectoral & $\begin{array}{l}\text { Large businesses and SMEs with } \\
\text { interests in Britain and Bangladesh }\end{array}$ \\
\hline Scottish Engineering & 1 & Regional & Manufacturing & SMEs \\
\hline Business Services Association & 1 & National & $\begin{array}{l}\text { Business Administration } \\
\text { and Support }\end{array}$ & Large Businesses \\
\hline Fresh Produce Consortium & 1 & National & Agriculture and Food Retail & SMEs \\
\hline $\begin{array}{c}\text { Representatives from } \\
\text { UK Internet Companies }\end{array}$ & 1 & National & $\begin{array}{l}\text { Information and } \\
\text { Communication }\end{array}$ & Not known \\
\hline British Chambers of Commerce & 1 & National & Multi-sectoral & $\begin{array}{c}\text { UK's } 53 \text { Accredited Chambers of } \\
\text { Commerce }\end{array}$ \\
\hline British/Irish Chamber of Commerce & 2 & Bi-lateral & Multi-sectoral & $\begin{array}{l}\text { Large businesses and SMEs with } \\
\text { interests in Britain and Ireland }\end{array}$ \\
\hline Retail Motor Industry Federation & 1 & National & Retail Motor Industry & Large Businesses and SMEs \\
\hline
\end{tabular}

organisation-met the Cabinet Office on 10 occasions whereas smaller firms' peak organisation-the FSB-only met the Cabinet Office once. It is tempting to conclude that the representatives of large firms are better at achieving access than smaller firms (mirroring the results for the firms themselves). However, most of the umbrella organisations featured here represent both large firms and SMEs-although smaller firms constitute the bulk of Chambers of Commerce memberships. Of the 15 umbrella organisations, nine are multi-sectoral (although Chambers of Commerce memberships are typically concentrated in high employment sectors such as manufacturing and construction) and it is possible that associations representing particular sectoral interests may be targeting the specific government bodies designed to deal with them (although neither is it known if these multi-sectoral bodies were raising sector-specific issues). Table 2 also includes bodies with sub-national, national and international remits. Excluding the CBI, umbrella bodies met the Cabinet Office just 15 times with only one doing so more than once-tentatively, it is possible to conclude that umbrella bodies do not find lobbying at this level easy and/or are limited to one-off transactional encounters. 


\subsection{Conclusion}

Corporate political activity in the UK is common and involves large numbers of businesses from a wide range of industrial sectors (with considerable sectoral variation). Larger firms enjoy far more access to government than small and medium-sized firms and most lobbying is undertaken by domestic firms because multinational firms may instead be targeting supranational political institutions. Umbrella bodies-especially those representing smaller businesses-are also underrepresented.

\section{Discussion}

In this section we revisit the propositions derived from the literature review. All-with the possible exception of Proposition 5-are supported by the data. Generally, UK businesses' CPA evidences no suis general properties and conforms to those known parameters developed in jurisdictions where lobbying is more closely scrutinised.

The findings confirm Proposition 1. Business interests from virtually all economic sectors met the Cabinet Office which must be seen as a prime target for many firms' CPA [59]; and the sheer number of meetings show that they are more-or-less daily events. The presence of the private sector at the very heart of government decision making is therefore seen as a legitimate and routine arrangement [72].

Proposition 2 is confirmed. Firms from almost every industrial sector featured, but there is sectoral variation. As neopluralists note, this may be because the state is not a neutral actor but, rather, an interest in its own right, more interested in seeking out policy formation and implementation advantages from certain sectors' key firms than others [27] [29] [41] [49]. Alternatively, in other sectors the state may retain key regulatory powers. From the firms' perspective, sectoral variation may reflect differences in the ability of certain sectors' business interests to assert their "go to" status [6] and perceptions regarding extant or looming threats and opportunities [5]. Further, whilst highly (state) regulated and politically charged sectors may evidence extensive political intervention [73], highly specialist sectors-technocratic backwaters about which governments know little-may be left alone. Sector-specific politics and vested interest, then, drives both parties' interactions and explains sectoral variation.

To use these ideas to explain precisely the sectoral variation we found would require a knowledge of the UK's industrial sectors and of the encounters themselves that we do not possess. Certainly, those sectors enjoying most access can be regarded as economic "big hitters", making significant contributions to the UK's GDP. As Warwick [74] observes, state-business interactions can reflect long-term strategic priorities (e.g. the UK's current industrial strategy prioritises science, technology and engineering) and sectoral approaches to developing the UK economy remain important (Department for Business, Innovation and Skills [75]). However, much state-business interactions are increasingly coalescing 
around horizontal (sub- and cross-sectoral) activities and themes including network-building, (de)regulation and innovation (Department for Business, Energy and Industrial Strategy [76]). Thus, although sectors are a convenient level of resolution, the variation they reveal may be obscuring alternative explanations of differentiated access.

Proposition 3 is confirmed. Large firms enjoy greater access to government than medium-sized firms; and small and micro-businesses barely figure. Large firms possess both the resources required to operationalise their CPA strategies and the access goods needed to be taken seriously. A highly unrepresentative brand of pluralism may be in operation. Large firms account for just $0.1 \%$ of all UK businesses and even medium-sized firms account for just $0.6 \%$-in other words, small businesses account for over $99 \%$ of all businesses. In terms of employees, the picture is still worrying-large businesses employ $40 \%$ of the UK workforce, compared to medium businesses (13\%) and small and micro businesses $(48 \%)$ [11].

As far as accessing the Cabinet Office is concerned the interests of the vast majority of businesses are thus not being heard. It may be wishful thinking, given the UK's "beggar thy neighbour" brand of capitalism [77], to assume large businesses are also looking out for the interests of smaller firms in their encounters.

Proposition 4 is confirmed. Despite their size transnational firms may not consider the Cabinet Office a legitimate target and may instead be lobbying supranationally. For example, lobbying at the EU level is dominated by multinational corporations because they are susceptible to EU-level policymaking [4] [18] [38] [41]. Conversely, national firms have greater knowledge of national political terrains, whilst national governments are keen to mine them for national policy formation and implementation advantages [4].

Some transnational firms do lobby nationally however. Stone [78] claims this is because they know that national governments retain influential roles in some international policymaking domains (including in an essentially intergovernmentalist EU). Clearly firms will take intelligent decisions regarding where to lobby. But the variables of "size", "international-ness" and "sector" probably interact-just as some sectors are more likely to contain large firms some sectors' firms are more internationally active and some sectors feature supranational as well as national policymaking and regulatory centres of decision-making.

Proposition 5 is partly confirmed. Several bodies representing a wide range of sectoral and multi-sectoral small and large businesses achieved occasional access; but the numbers are modest and (almost) the sole umbrella body enjoying repeated access to the Cabinet Office represented large businesses.

Historically, many UK business associations have been voluntaristic and informal and their fundamental effectiveness has frequently been questioned [25] [79]. Alternatively, it may be that the small and micro-business sector is just so diverse and dispersed that it is relatively unorganisable [37]. Finally, just like transnational corporations, it may be that smaller businesses are venue shopping 
and do not see central government as a primary or realistic target (hoping, perhaps, that larger firms' CPA will generate positive spillover).

Proposition 6 is confirmed. CPA is extremely common and despite sectoral variation no single policy sector can easily be described as dominant. This may be evidence of ad hoc transactional lobbying comprising large numbers of one-off encounters by businesses and government reacting to existing or anticipated policy developments. But there is also some evidence of a more relational approach in operation.

\section{Conclusions}

The research features several limitations. First, equating access with influence is problematic-both because much lobbying in the UK remains invisible and because accessing decision-makers is no guarantee of getting them to do what you want. However, access is commonly used as a proxy for influence [4] [18] [38]. Second, neither is access an accurate indicator of the commonality of $\mathrm{CPA}-$ many more firms may have sought meetings with the Cabinet Office but failed. Third, whilst the Cabinet Office occupies a strategic position at the centre of UK policymaking many corporate interests may be (successfully) directing their CPA elsewhere. Fourth, the data provides no information regarding the nature of any encounters and although repeated access is suggestive of a relational approach this cannot be asserted unequivocally. Fourth, the reduced sample of the firm size analysis is frustrating (although there is no prima facie reason to suggest it is unrepresentative). Fifth, time constraints have prevented at least one important variable-company age-from being addressed. Age may be important because it takes time for firms to grow and develop the confidence, know-how, reputation and resources to engage in CPA [80] [81]. Finally, this is a "snapshot" only and does not identify any trends.

Our overall findings suggest that the patterning of CPA in the UK-hitherto relatively unregulated and invisible-yields few surprises and can be understood using orthodox understandings, including those derived from jurisdictions where it has been more regulated and better understood. There is therefore a need to better comprehend why lobbying in the UK, comparatively unfettered, evidences few suis general characteristics-and, by extension, the impact of regulation. Regulation can certainly render CPA (more) visible, enabling publics to draw links between lobbyists and government decision-makers, but may not affect the asymmetries of power of its principal actors [82] - put differently, regulation does not affect the "game" itself but simply provides it with an audience. Chari et al. [50] argue that regulation is primarily focused on increasing transparency rather than rooting-out corruption, finding no link between the robustness of regulatory systems and levels of wrongdoing-in other words, the presence or absence of regulation is not significantly behaviour-changing. In shining a long overdue light on lobbying in the UK our research appears to support this view. 


\section{Conflicts of Interest}

The authors declare no conflicts of interest regarding the publication of this paper.

\section{References}

[1] Smith, M.J. (1995) Pressure Groups. Baseline Books, Manchester.

[2] Rhodes, R.A.W. (1997) Understanding Governance: Policy Networks, Governance, Reflexivity and Accountability. Open University Press, Buckingham.

[3] Peters, B.G. and Pierre, J. (1998) Governance without Government? Rethinking Public Administration. Journal of Public Administration Research and Theory, 8, 223-243. https://doi.org/10.1093/oxfordjournals.jpart.a024379

[4] Eising, R. (2007) The Access of Business Interests to EU Institutions: Towards Élite Pluralism? Journal of European Public Policy, 14, 384-403. https://doi.org/10.1080/13501760701243772

[5] Chen, H., Parsley, D. and Yang, Y.W. (2015) Corporate Lobbying and Firm Performance. Journal of Business Finance and Accounting, 42, 444-481. https://doi.org/10.1111/jbfa.12109

[6] Drutman, L. (2015) The Business of America Is Lobbying: How Corporations Became Politicized and Politics Became More Corporate. Oxford University Press, Oxford. https://doi.org/10.1093/acprof:oso/9780190215514.001.0001

[7] Dowding, K. (2012) Why Should We Care about the Definition of Power? Journal of Political Power, 5, 119-135. https://doi.org/10.1080/2158379X.2012.661917

[8] Hawkins, B. and Holden, C. (2014) Water Dripping on Stone? Industry Lobbying and UK Alcohol Policy. Policy and Politics, 42, 55-70. https://doi.org/10.1332/030557312X655468

[9] Hillman, A.J. (2003) Determinants of Political Strategies in U.S. Multinationals. Business and Society, 42, 455-484. https://doi.org/10.1177/0007650303260351

[10] Hafner-Fink, M., Nowak, M., Eising, R., Rasch, D. and Rozbicka, P. (2016) Giants and Dwarfs: The Multilevel Lobbying Strategies of National Interest Organizations. Teorija in Praksa, 53, 605-624.

[11] Rhodes, C. (2018) Business Statistics. Briefing Paper Number 06152. House of Commons Library, London.

[12] Getz, K.A. (2002) Public Affairs and Political Strategy: Theoretical Foundations. Journal of Public Affairs, 1, 305-329. https://doi.org/10.1002/pa.77

[13] Lawton, T. and Rajwani, T. (2011) Designing Lobbying Capabilities: Managerial Choices in Unpredictable Environments. European Business Review, 23, 167-189. https://doi.org/10.1108/09555341111111192

[14] Lawton, T., McGuire, S. and Rajwani, T. (2013) Corporate Political Activity: A Literature Review and Research Agenda. International Journal of Management Reviews, 15, 86-105. https://doi.org/10.1111/j.1468-2370.2012.00337.x

[15] Baumgartner, F.R., Berry, J.M., Hojnacki, M., Kimball, D.C. and Leech, B.L. (2009) Lobbying and Policy Change: Who Wins, Who Loses, and Why. University of Chicago Press, Chicago. https://doi.org/10.7208/chicago/9780226039466.001.0001

[16] Hall, P.A. (1993) Policy Paradigms, Social Learning, and the State: The Case of Economic Policymaking in Britain. Comparative Politics, 25, 275-296. https://doi.org/10.2307/422246 
[17] Baldwin, R., Cave, M. and Lodge, M. (2012) Understanding Regulation: Theory, Strategy, and Practice. Oxford University Press, Oxford. https://doi.org/10.1093/acprof:osobl/9780199576081.001.0001

[18] Bouwen, P. (2002) Corporate Lobbying in the European Union: The Logic of Access. Journal of European Public Policy, 9, 365-390. https://doi.org/10.1080/13501760210138796

[19] Eising, R. (2008) Interest Groups in EU Policy-Making. Living Reviews in European Governance, 3, 4-32. https://doi.org/10.12942/lreg-2008-4

[20] Miller, D. and Dinan, W. (2008) A Century of Spin. Pluto, London.

[21] Smith, K.E., Fooks, G., Gilmore, A.B., Collin, J. and Weishaar, H. (2015) Corporate Coalitions and Policy Making in the European Union: How and Why British American Tobacco Promoted "Better Regulation". Journal of Health Politics, Policy and Law, 40, 325-372. https://doi.org/10.1215/03616878-2882231

[22] Moss, D. (1990) Public Relations in Practice. Routledge, London.

[23] Hillman, A.J. and Hitt, M.A. (1999) Corporate Political Strategy Formulation: A Model of Approach, Participation and Strategy Decisions. Academy of Management Review, 24, 825-842. https://doi.org/10.5465/amr.1999.2553256

[24] Coen, D. (1997) The European Business Lobby. Business Strategy Review, 8, 17-25. https://doi.org/10.1111/1467-8616.00044

[25] Bennett, R. (1997) The Relation between Government and Business Associations in Britain: An Evaluation of Recent Developments. Journal of Policy Studies, 18, 5-33. https://doi.org/10.1080/01442879708423719

[26] Greenwood, J. (2003) Interest Representation in the European Union. Palgrave Macmillan, Basingstoke.

[27] Grant, W. (1993) Business and Politics in Britain. Macmillan, London. https://doi.org/10.1007/978-1-349-22875-1

[28] Miller, D. (2009) Corporate Lobbying's New Frontier: From Influencing Policy-Making to Shaping Public Debate. In: Zinnbauerm, D., Ed., Global Corruption Report, Cambridge University Press in Association with Transparency International, Cambridge, 39-41.

[29] Jordan, G. (1991) The Commercial Lobbyists: Politics for Profit in Britain. Aberdeen University Press, Aberdeen.

[30] Wilson, D. (1993) Campaigning: The A-Z of Advocacy. Hawkesmere, London.

[31] Richards, D. and Smith, M. (2002) Governance and Public Policy in the UK. Oxford University Press, Oxford.

[32] Bekke, H.A.G.M., Kickert, W.J.M. and Kooiman, J. (1995) Public Management and Governance. In: Kickert, W.J.M. and van Vught, F.A., Eds., Public Policy and Administrative Sciences in the Netherlands, Harvester-Wheatsheaf, London, 201-218.

[33] Rhodes, R.A.W. (1994) The Hollowing out of the State: The Changing Nature of the Public Service in Britain. Political Quarterly, 65, 138-151. https://doi.org/10.1111/j.1467-923X.1994.tb00441.x

[34] Bulmer, S. (1983) Domestic Politics and European Community Policy-Making. Journal of Common Market Studies, 21, 349-364. https://doi.org/10.1111/j.1468-5965.1983.tb00265.x

[35] Bulmer, S. (2001) The New Institutional Politics: Performance and Outcomes. Political Studies, 49, 1075-1075.

[36] Schuler, D.A. and Rehbein, K. (2011) Determinants of Access to Legislative and Ex- 
ecutive Branch Officials: Business Firms and Trade Policymaking in the US. Business and Politics, 13, 1-30. https://doi.org/10.2202/1469-3569.1340

[37] Marlow, S. (2005) Introduction. In: Marlow, S., Patton, D. and Ram, M., Eds., Managing Labour in Small Firms, Routledge, London, 1-14. https://doi.org/10.4324/9780203495612

[38] Bouwen, P. (2002b) A Comparative Study of Business Lobbying in the European Parliament, the European Commission and the Council of Ministers (Max-Planck-Institute Discussion Paper 02/7). Max-Planck-Institut für Gesellschaftsforschung, Köln.

[39] Hennessy, P. (1995) The Hidden Wiring. Victor Gollancz, London.

[40] Jones, B. (1991) Politics UK. Philip Allan, Hemel Hempstead.

[41] Hauser, H. (2011) European Union Lobbying Post-Lisbon: An Economic Analysis. Berkeley Journal of International Law, 29, 680-709.

[42] Grant, W. (1995) Pressure Groups, Politics and Democracy in Britain. Harvester Wheatsheaf, Hemel Hempstead. https://doi.org/10.1007/978-1-349-15022-9

[43] Kooiman, J. (1993) Social-Political Governance: Introduction. In: Kooiman, J., Ed., Modern Governance: New Government-Society Interactions, Sage, Newbury Park, 1-8.

[44] Baldwin, R., Scott, C. and Hood, C. (1998) A Reader on Regulation. Oxford University Press, Oxford. https://doi.org/10.1093/acprof:oso/9780198765295.001.0001

[45] Jordan, A.G. and Maloney, W.M. (1997) The Protest Business. Manchester University Press, Manchester.

[46] Dahl, R.A. (1982) Dilemmas of Pluralist Democracy: Autonomy vs. Control. Yale University Press, New Haven.

[47] Harris, P. and Lock, A. (1996) Machiavellian Marketing: The Development of Corporate Lobbying in the UK. Journal of Marketing Management, 12, 313-328. https://doi.org/10.1080/0267257X.1996.9964417

[48] Lindblom, C.E. (1977) Politics and Markets. Basic Books, New York.

[49] Mahoney, C. (2004) The Power of Institutions State and Interest Group Activity in the European Union. European Union Politics, 5, 441-466.

https://doi.org/10.1177/1465116504047312

[50] Chari, R., Hogan, J. and Murphy, M. (2010) Regulating Lobbying. Manchester University Press, Manchester.

[51] Blick, A. (2004) People Who Live in the Dark. Politicos, London.

[52] Andrews, L. (1996) The Relationship of Political Marketing to Political Lobbying. European Journal of Marketing, 30, 76-99. https://doi.org/10.1108/03090569610149809

[53] Cowles, M.G. (2001) The Transatlantic Business Dialogue and Domestic Business-Government Relations. In: Cowles, M.G., Caporaso, J.A. and Risse, T., Eds., Transforming Europe: Europeanization and Domestic Change, Cornell University Press, Ithaca, 159-179. https://doi.org/10.7591/9781501723575-010

[54] Hennessy, P. (2000) The Blair Style and the Requirements of Twenty-First Century Premiership. The Political Quarterly, 71, 386-395. https://doi.org/10.1111/1467-923X.00326

[55] Mahon, J.F. (2002) Corporate Reputation: A Research Agenda Using Strategy and Stakeholder Literature. Business and Society, 41, 415-445.

https://doi.org/10.1177/0007650302238776 
[56] Grossman, G.M. and Helpman, E.M. (2001) Special Interest Politics. MIT Press, Cambridge and London.

[57] Keillor, B.D., Wilkinson, T.J. and Owens, D. (2005) Threats to International Operations: Dealing with Political Risk at the Firm Level. Journal of Business Research, 58, 629-635. https://doi.org/10.1016/j.jbusres.2003.08.006

[58] Gordon, S.C. and Hafer, C. (2005) Flexing Muscle: Corporate Political Expenditures as Signals to the Bureaucracy. American Political Science Review, 99, 245-261. https://doi.org/10.1017/S0003055405051634

[59] Blick, A. and Jones, G. (2010) Premiership: The Development, Nature and Power of the Office of the British Prime Minister. Imprint Academic, Exeter.

[60] Boleat, M. (2000) Models of Trade Association Co-Operation. http://www.boleat.com/materials/MTAC 2000.pdf

[61] Gregor, M. (2011) Corporate Lobbying: A Review of the Recent Literature (IES Working Paper 32/2011). https://doi.org/10.2139/ssrn.1978724 http://ies.fsv.cuni.cz/sci/publication/show/id/4416/lang/en

[62] Hojnacki, M. (1997) Interest Groups' Decisions to Join Alliances or Work Alone. American Journal of Political Science, 41, 61-87. https://doi.org/10.2307/2111709

[63] Obach, B. (2002) Labour-Environmental Relations: An Analysis of the Relationship between Labour Unions and Environmentalists. Social Science Quarterly, 83, 82-100. https://doi.org/10.1111/1540-6237.00072

[64] Baumgartner, F.R., Bryan, D. and Jones, B. (1991) Agenda Dynamics and Policy Subsystems. Journal of Politics, 53, 1044-1074. https://doi.org/10.2307/2131866

[65] Kavanagh, D. (2001) New Labour, New Millenium, New Premiership. In: Seldon, A., Ed., The Blair Effect. The Blair Government 1997-2001, Little Brown and Co., London, 3-120.

[66] Downs, A. (1972) Up and Down with Ecology-The Issue-Attention Cycle. Public Interest, 28, 38-50.

[67] Kingdon, J. (1984) Agendas, Alternatives, and Public Policies. Little Brown, Boston.

[68] Baumgartner, F.R. and Leech, B.L. (2001) Issue Niches and Policy Bandwagons: Patterns of Interest Group Involvement in National Politics. Journal of Politics, 63, 1191-1213. https://doi.org/10.1111/0022-3816.00106

[69] Lord, M.D. (2000) Corporate Political Strategy and Legislative Decision Making: The Impact of Corporate Legislative Influence Activities. Business and Society, 39, 76-93. https://doi.org/10.1177/000765030003900106

[70] Anastasiadis, S. (2006) Understanding Corporate Lobbying on Its Own Terms (ICCSR Research Paper Series, 42). International Centre for Corporate Social Responsibility, Nottingham.

[71] Office for National Statistics. Activity, Size and Location. https://www.ons.gov.uk/businessindustryandtrade/business/activitysizeandlocation

[72] Calingaert, M. (1992) Business-Government Relations. Committee on Foreign Affairs of the US House of Representatives, Europe and the United States: Competition and Co-Operation in the 1990s. US Government Printing Office, Washington DC.

[73] Majone, G. (1994) The Rise of the Regulatory State in Europe. West European Politics, 17, 77-101. https://doi.org/10.1080/01402389408425031

[74] Warwick, K. (2013) Beyond Industrial Policy: Emerging Issues and New Trends, (OECD Science, Technology and Industry Policy Paper, No. 2). OECD Publishing, 
Paris.

[75] Department for Business, Innovation and Skills (2012) BIS Economics Paper No. 18, Industrial Strategy: UK Sector Analysis. BIS, London.

[76] Department for Business, Energy and Industrial Strategy (2017) Building Our Industrial Strategy. BEIS, London.

[77] Hall, P.A. and Soskice, D. (2001) Varieties of Capitalism: The Institutional Foundations of Comparative Advantage. Oxford University Press, Oxford. https://doi.org/10.1093/0199247757.001.0001

[78] Stone, D. (2004) Transfer Agents and Global Networks in the "Transnationalisation" of Policy. Journal of European Public Policy, 11, 545-566. https://doi.org/10.1080/13501760410001694291

[79] Jordan, G., Maloney, W.M. and McLaughlin, A.M. (1993) Corporate Lobbying in the European Community. Journal of Common Market Studies, 31, 191-212. https://doi.org/10.1111/j.1468-5965.1993.tb00457.x

[80] Boddewyn, T. and Brewer, L. (1994) International-Business Political Behavior: New Theoretical Direction. Academy of Management Review, 19, 119-143. https://doi.org/10.5465/amr.1994.9410122010

[81] Campos, N.F. and Giovannoni, F. (2007) Lobbying, Corruption and Political Influence. Public Choice, 131, 1-21. https://doi.org/10.1007/s11127-006-9102-4

[82] Thomas, C.S. (2005) Lobbying in the United States: An Overview for Students, Scholars and Practitioner. In: Harris, P. and Fleischer, C., Eds., The Handbook of Public Affairs, Sage, London, 281-303. https://doi.org/10.4135/9781848608108.n18 